\title{
Research Status of Airbag Buffer Landing Device in China
}

\author{
Ruikun Huo 1, a , Xu Li 2, b, Minggang Han 3, c \\ ${ }^{1}$ Mechanical Engineering College, Shijiazhuang 050003, China; \\ ${ }^{2}$ Beijing Military Representative Office, Shijiazhuang 050003, China; \\ 395985 Troops, Kaifeng 475000, China. \\ ahuanyutian1113@163.com, b764468402@qq.com, chanmg111@163.com
}

Keywords: airdrop, airbag, buffer, research status.

\begin{abstract}
The airbag buffer landing device is an important part of the existing buffer device in China. Its low cost, flexible and lightweight, safe and reliable excellent features play an important role in the field of airdrop and aerospace. This paper summarizes the classification and research methods of the current airbag buffer landing device, and systematically summarizes its advantages and disadvantages, modeling and model optimization methods, airbag cushioning characteristics and so on, and puts forward the development trend of the airbag buffer landing device.
\end{abstract}

\section{Introduction}

Airdrop is an action of using aircraft to transport military equipments and materials from the air to the designated locations, which is a means of transporting weapons and supplies and equipments in military operations. And in the country's construction, it can airdrop relief supplies to support remote and traffic inconvenience areas, as well as disaster relief [1]. The landing cushioning device plays a vital role in the safe landing of the equipment materials, and its main way is to use the structural energy absorption device or buffer energy absorbing materials to transfer the landing impact energy, reduce the landing impact force and the landing overload, so as to ensure the safeties of equipments. Therefore, the principle, structure, advantages and disadvantages of existing landing buffers are summarized, and the research methods are summarized, which are of great significance to the development of airborne buffer devices.

\section{Classification of Buffer Airbag}

Landing buffer device can effectively compensate for the requirements of the descending speed of the parachute, reduce its area and residence time, and reduce the possibility of air damage. And more categories, according to the number of effective work can be divided into one-time and re-use of two categories, and according to the main types of activities are divided into the following two categories [2]: 1. Before landing to reduce the landing speed instantaneously.2. After landing absorption, dissipation of landing energy. The details are shown in Figure 1.

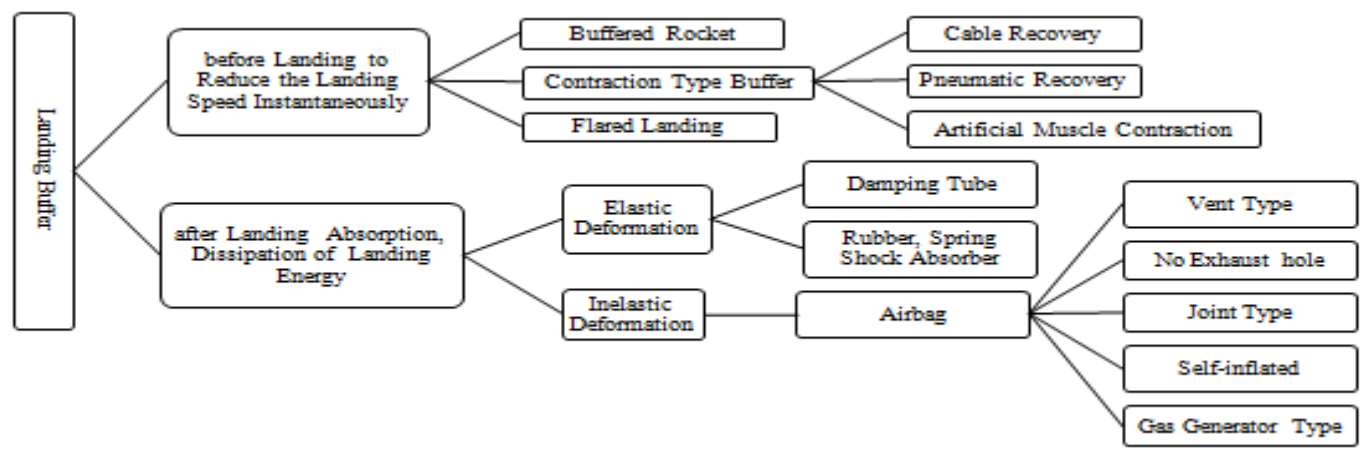

Fig. 1 Classification of buffer device 
The airbag cushioning device has the advantages of flexibility, simplicity, light weight, low cost, safe, reliable and reusable. And it is widely used in airdrop and aerospace, which is mainly the use of compressed airbag deformation of the effective absorption of impact energy, and ensure the safe landing of equipment. According to the structure can be divided into a vent type, no exhaust type and with or without vent hole joint type, and according to the inflatable way can be divided into self-inflatable and gas generator inflatable, its structure and advantages and disadvantages as shown in Table 1.

Table 1. Airbag buffer structure advantages and disadvantages

\begin{tabular}{|c|c|c|c|c|}
\hline \multicolumn{2}{|c|}{ Buffered Form } & Structural Features & Advantages & Disadvantages \\
\hline \multirow{2}{*}{ 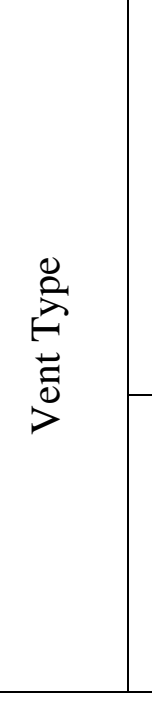 } & 离 & $\begin{array}{l}\text { The air bag around the } \\
\text { distribution of holes, } \\
\text { when a certain } \\
\text { threshold, the exhaust } \\
\text { hole to open the exhaust, } \\
\text { and the exhaust port } \\
\text { area fixed }\end{array}$ & $\begin{array}{l}\text { One-time buffer, } \\
\text { reduce the rebound } \\
\text { and flip, the volume is } \\
\text { relatively small }\end{array}$ & $\begin{array}{l}\text { Structural design complexity, } \\
\text { vent position, opening } \\
\text { threshold, exhaust flow and } \\
\text { other parameters affected by } \\
\text { the environment significantly } \\
\text { to determine the difficulties, } \\
\text { reliability, prone to secondary } \\
\text { shock }\end{array}$ \\
\hline & $\begin{array}{l}\frac{0}{0} \\
\frac{0}{\overline{0}} \\
0 \\
0 \\
0 \\
0\end{array}$ & $\begin{array}{l}\text { Load the exhaust control } \\
\text { device to control the } \\
\text { outlet opening area }\end{array}$ & $\begin{array}{l}\text { Airbag pressure can } \\
\text { be constant to } \\
\text { maintain a certain } \\
\text { time, high buffer } \\
\text { efficiency, to avoid } \\
\text { secondary shock }\end{array}$ & $\begin{array}{c}\text { The control device is complex } \\
\text { and the design parameters are } \\
\text { limited }\end{array}$ \\
\hline 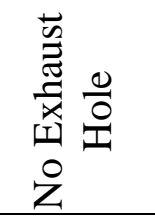 & & One-piece closed airbag & $\begin{array}{l}\text { Simple structure, easy } \\
\text { to produce, good } \\
\text { reliability, } \\
\text { omnidirectional buffer }\end{array}$ & $\begin{array}{c}\text { Rebounded significantly, easy } \\
\text { to flip, rupture caused by } \\
\text { buffer failure }\end{array}$ \\
\hline 总 & & $\begin{array}{l}\text { The middle distribution } \\
\text { is not exhausted around } \\
\text { the distribution of } \\
\text { exhaust holes }\end{array}$ & $\begin{array}{l}\text { Buffer more stable, } \\
\text { effectively reducing } \\
\text { the rebound and flip }\end{array}$ & $\begin{array}{l}\text { Structural design is complex, } \\
\text { difficult to determine the } \\
\text { parameters, not easy to achieve }\end{array}$ \\
\hline 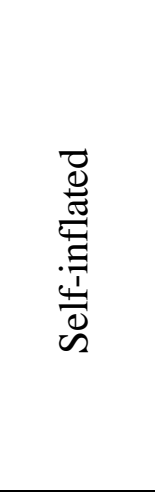 & & $\begin{array}{l}\text { Descending process to } \\
\text { rely on the speed of the } \\
\text { role of the pressure in } \\
\text { the airbag, when a } \\
\text { certain threshold to } \\
\text { achieve when the air } \\
\text { inlet open inflatable }\end{array}$ & $\begin{array}{l}\text { Simple and } \\
\text { lightweight, can be } \\
\text { closely integrated } \\
\text { with the umbrella } \\
\text { descent speed, a } \\
\text { certain range to } \\
\text { achieve the buffer } \\
\text { effect increases with } \\
\text { the landing speed } \\
\text { increases }\end{array}$ & $\begin{array}{l}\text { Gas stamping flow is not } \\
\text { control, the buffer effect by the } \\
\text { external conditions of the } \\
\text { larger fluctuations }\end{array}$ \\
\hline 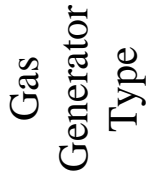 & & $\begin{array}{l}\text { Built-in gas generator } \\
\text { and supporting trigger } \\
\text { device }\end{array}$ & $\begin{array}{c}\text { The airbag can be well } \\
\text { opened to the preset } \\
\text { level }\end{array}$ & $\begin{array}{l}\text { Complex structure, the relative } \\
\text { increase in quality }\end{array}$ \\
\hline
\end{tabular}




\section{Research Methods}

The process of airbag buffering is a complex process of nonlinear multi-factor coupling, which is carried out by numerical simulation method and experiment. And the experimental method is tested by observing and analyzing the relationship between the data processing and the fitting curve evaluation parameters. And numerical simulation is based on the establishment and revision of the model, which is based on the analysis and modification of the characteristics. Finally, the improvement of the guidance model and the selection of the parameters are compared with the experimental method and the numerical simulation.

\subsection{Airbag Models Establishment and Revision.}

The accuracy of the model is very close to the simulation model of the model, and its accuracy directly affects the final simulation results. Therefore, it is very important to establish the method and simplify the algorithm.

Airbag Models Establishment.

There are control volume method (CV), arbitrary Lagrange-Euler method (ALE) and corpuscular method (CPM). At present, most of the airbag simulation uses the control volume method (CV), which is simple to model, but ignores the influence of airflow in the airbag. And the ALE method can facilitate the flow field analysis, but its main problem is that the modeling process is more complex, and the calculation of high cost. In recent years, a new corpuscular method (CPM) based on gas molecular dynamics has been developed, K. Mroz and B. Pipkorn used the CPM method to simulate the static expansion and impact test of the folded airbag. And the simulation results are in good agreement with the experimental results [3]. Compared with the ALE method and the CV method, although the particle method has its own advantages, but China for the method of research and application is not much [4]

Airbag Models Revision.

Hong Huangjie, Li Jianyang et al have sought an alternative model [5] for the shortcomings of the model established by the above method in the simulation simulation, That is, the application of hypercube design method to radial basis function proxy model to participate in the original simulation process, greatly simplifies the model and simulation of the amount of calculation, and verify the effectiveness of the model. On the basis of this, the Monte Carlo method is used to evaluate the whole buffer performance, and the response characteristics of the airbag cushioning system under various working conditions are obtained quickly and easily when the simulation data demand is quite large.

He Qian et al use the D-optimal experimental design method combined with the Moving Least Squares (MLS) constructor model [6]. In the case of simplified model and computational complexity, the response of the airbag to strong impact load is well simulated. Based on this, the parameter optimization analysis is carried out, and the conclusion that the maximum overload of the landing increases with the initial pressure and shrinkage stiffness of the airbag is given.

\subsection{Airbag Characteristics Analysis and Parameter Optimization}

The characteristics of airbag directly determine the effect of landing buffer. The study of its characteristics can reveal its inherent attributes, better control and master its external performance, which provides theoretical support for rational modeling and optimization analysis. According to the existing literature, Can summarize its main features are as follow [7-10]:

1. The maximum pressure of the airbag and the landing peak acceleration increase with the increase of the land velocity, and the landing peak acceleration decreases with the increase of the load mass.

2. Exhaust area is an important parameter of the performance of the cushion airbag, the performance of the exhaust port is relatively enhanced, and its reasonable design can effectively avoid the rebound when the buffer.

3. The factors such as the mass of airdrop, the speed of landing, the area of the exhaust port, the angle of the ground and the height of the airspace have a significant effect on the cushioning performance of the airbag, and the factors are mutually coupled. And these links should be focused on in the design and analysis. 
4. The elastic modulus of low elastic modulus in the simulation of its impact can not be ignored, otherwise the corresponding value is low 。

5. The design parameters that affect the cushioning effect of the airbag mainly include the main airbag height, lateral width, the area of the exhaust hole, the weaving material and so on, and there are multi-factor coupling phenomena, and the reasonable selection of the parameters can achieve the best buffer effect. And the optimization method can be a single target method or multi-objective method.

\section{Conclusion}

Airbag landing buffer device because of its low cost, flexible and lightweight, safe and reliable excellent features in the field of air and aerospace play an important role in the combination of test and numerical simulation method, which has important practical significance in the future study. First, the new simulation model construction method and simplified method of exploration, so that the operation closer to the actual results, the second is the combination of airbags and other buffer devices, two or more buffer device combination to make up for the airbag in the buffer process of the rebound, Flip or failure, so that the buffer effect is more safe and efficient.

\section{References}

[1]. Zhen Liu, Wusheng Zhang. Airborne Training and Technology [M]. Guangxi: Guilin Air Force Academy, 2006, p. 1.

[2]. Chengguo $\mathrm{Yu}$, Liangchun Li. Ways of Air-drop Safety Landing[J]. PACKAGING ENGINEERING. Vol. 28 (2007) No. 10, p. 135-137.

[3]. Mroz K, Pipkorn B. Mathematical modeling of the early phase deployment of a passenger airbag-folding using origami theory and inflation using LS-DYNA particle method[C]. 6th European LS-DYNA Users' Conf. Sweden, 2006, p. 4.71-4.86.

[4]. Kaikai Che, Meisong Wang. Comparison on three methods for simulating safety airbag deployment[J]. Automotive Safety and Energy. Vol. 4 (2013) No. 3, p. 250-256.

[5]. HONG Huangjie, WANG Hongyan, LI Jianyang, et al. Research on Assessment Method of Cushion System for Airdropping Equipment[J]. JOURNAL OF MECHANICAL ENGINEE RING. Vol. 51 (2015) No. 4, p. 148-154.

[6]. HE Cheng, CHEN Guoping, HE Huan, et al. Multi-objective Optimization of Impact Dynamics for Airbag Cushion Landing System[J]. SPACECRAFT RECOVERY \& REMOTE SENSING. Vol. 33 (2012) No. 5, p. 1-8.

[7]. Lü Zhen-yuan, WANG Hong-yan, HONG Huang-jie et al. Cushioning Properties Analysis and Matching Method of Airbag Cushioning System for Airdropped Equipment[J]. Journal of Academy of Armored Force Engineering. Vol. 28 (2014) No. 4, p. 34-39.

[8]. QU Pu, SHI Rui, LI Jin-hong, et al. Numerical Simulation of Multi-airbags Buffer Landing System[J]. Fire Control \& Command Control. Vol. 40 (2015) No. 3, p. 125-129.

[9]. WEN Jin-peng, LI Bin, TAN De-wei, et al. Study on cushioning characteristics of soft landing airbag considering weaving elasticity [J]. JOURNAL OF VIBRATION AND SHOCK. Vol. 29 (2010) No. 2, p. 79-83.

[10]. WANG Hong-yan, HONG Huang-jie, LI Jian-yang. Research on Simulation and Optimization of Cushion Characteristic of Airbags for Airborne Vehicle[J]. ACTA ARMAMENTAR II . Vol. 33 (2012) No. 12, p. 1461-1466. 